\title{
Understanding Trend and Variation of Electrical Energy usage Among Students in the National University of Malaysia
}

\author{
Noorazuan Md Hashim, Muhammad Khaidir Bin Azmi, Yaakob Mohd Jani \\ Social, Environmental and Developmental Sustainability Research Centre (SEEDS), \\ The National University of Malaysia, UKM Bangi, Malaysia
}

\begin{abstract}
How to cite this paper: Noorazuan Md Hashim | Muhammad Khaidir Bin Azmi | Yaakob Mohd Jani "Understanding Trend and Variation of Electrical Energy usage Among Students in the National University of Malaysia" Published in International Journal of Trend in Scientific Research and Development

(ijtsrd), ISSN: 2456-

6470, Volume-3 |

Issue-3, April 2019,

pp. 31-35.

http://www.ijtsrd.co

$\mathrm{m} /$ papers/ijtsrd 215

86.pdf

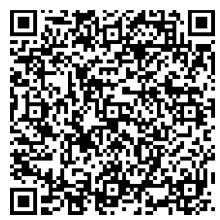

IJTSRD21586
\end{abstract}

Copyright (C) 2019 by author(s) and International Journal of Trend in Scientific Research and Development Journal. This is an Open Access article distributed under the terms of the Creative Commons

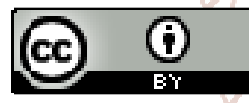
Attribution License (CC BY 4.0) (http://creativecommons.org/licenses/ by/4.0)

\section{INTRODUCTION}

Universiti Kebangsaan Malaysia (UKM) located in Bangi, Selangor is one of the oldest and prestigious public educational institutions in Malaysia. UKM is among the top public universities that have opened up student intake every year and devoted in providing quality education to Malaysians. Over 20 thousand students enrolled in UKM consisting of pre and post-graduate students coming from Malaysia and foreign countries. The uptrend of students has further increased the consumption rate of electricity in UKM. This has triggered issues and pressures to the University's manager in handling utility budget.

Majority of university residents are students who spend most of their time on campus. In order to achieve learning goals, the students indirectly use electricity, whether wisely or otherwise. A study done by CRED (2009) has shown that a total of $251,000 \mathrm{Kwh} /$ month of electricity or RM $74,000 /$ month is used for utility costs at the Faculty of Social Science and Humanities. The amount is considered high and requires an in-depth study on the aspects of consumer electricity consumption in UKM. The faculty is also seen to have no scientific laboratories or experimental spaces which have greater energy requirements.
Past studies have also shown an unhealthy trend on campus, where students are less concerned with energy consumption rates and their savings initiatives (Choong et al, 2012; Nur Najihah 2013; Khaidir, 2019). Thus, this paper is aimed at identifying the use of electricity used especially between residential colleges at Universiti Kebangsaan Malaysia, as well as identifying practical savings initiatives in the residential colleges.

\section{Research background}

One of the factors of increasing greenhouse gas concentration in atmosphere is due to the generation of electricity through the burning of fossil materials. This means that the higher usage of energy will increases the concentration of $\mathrm{CO}_{2}$ released into the atmosphere. Although it is regarded as a human need, it is a major cause of global climate change (Olivia et al, 2009). The need for electricity will continue to increase in line with Malaysia's objective of achieving a developed nation status by 2020 . However, overutilization of electricity potentially creates risk and disaster to future generation. From time to time, electricity tariff rates are rising in tandem with rising energy generation costs. The Energy Commission through Tenaga Nasional 
Berhad uses a mechanism that is referred to as Incentive Based Regulation (IBR) which enables fuel costs to be adjusted every six months based on fluctuations in global fuel prices. Hence, the government has to allocate RM150 million subsidy per year to ease the burden of consumers in Peninsular Malaysia, Sabah and Sarawak.

According to Mohd Noor (2016) the household electrical appliances market in Malaysia has increased from year to year. For example, refrigerators' market size has grown from 148,000 units in 1998 to 162,000 units in 2000. While washing machines have increased from 235,000 units in 1998 to 270,000 units in 2000. This suggests that the usage would certainly affected the demand for energy in Malaysia.

In addition to industries and households, the use of energy in higher education institutions also contributes to the increase in electrical expenditures in Malaysia. In a study done by Mohd Noor et al. (2016), the Electrical Appliance Review Study states that the total electricity bills at Kolej Dato 'Onn Jaafar, Universiti Teknologi Malaysia, in 2011 increased by RM56,220.99 or 16.5 per cent from RM339,881.11 in 2011 to RM396,102.10 in the year 2012. The increase in the cost is still ongoing eventhough sustainable electricity usage policy has been established to reduce the amount of electricity consumption.

Although the objective of energy usage is to provide comfort to individuals and communities, but the use should be efficient and prudent (Sanurya 2014; Brandon 2009). Ventilation systems such as air conditioners, for example are the largest components that utilised electrical energy in Malaysia. According to Jadin et al (2008), energy saving can be done efficiently and effectively by using timer control tools to reduce the use of air conditioners when rooms or booths are not being used. The tool is set automatically in some rooms and lectures hall. As a result, they found that the average annual energy saving was RM 5,881.92.

Brandon (2009) conducted a study to view electricity use in student housing at Pennsylvania University, USA. The high electricity consumption is due to the use of refrigerators. In addition, survey respondents point out that students are prepared to support a sustainable initiative on campus, including provision of energy-efficient refrigerators.. Finally, according to survey results, the most effective initiative in reducing electricity consumption requires individual meter to detect electricity consumption.

While energy saving may sometimes conflict with comfort, it's possible to eliminate excessive use of wasteful energy can be done without compromising comfort (Shashi 2016). Global climate change is not the only factor why electric power should be used prudently in Malaysia. Actually, the increase in electricity rates or tariffs in Malaysia, the unpredictable inflation and economic downturn problems are also an important factor in implementing electricity conservation measures or initiatives (Tiwi 2013). As students use electronic gadgets like smartphones and computers, have they ever wondered where the energy came from? Have they ever wondered if the government had to cover the cost of generating energy in the form of large subsidies to facilitate their life in the campus?

\section{Study Area and method}

The main campus of Universiti Kebangsaan Malaysia (UKM) is located at latitude $\mathrm{N} 2^{\circ} 55^{\prime} 42.07$ " and longitude E $101^{\circ}$ 47' 14.63" (Figure 1). According to the UKM Development and Planning Department, the UKM area of Bangi campus is about 32 kilometers south of the Kuala Lumpur City Center and 8 kilometers to the South Bandar Kajang, which is the capital of Hulu Langat, Selangor.

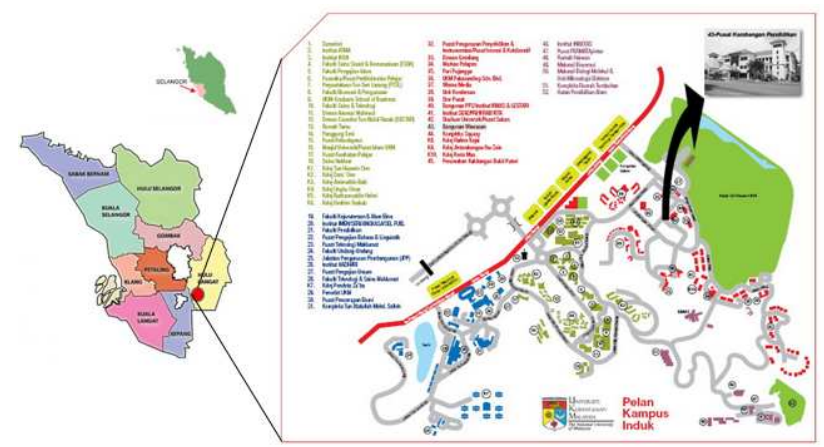

Fig1. Location of UKM Bangi, Selangor, Malaysia

Universiti Kebangsaan Malaysia Bangi campus has ten residential colleges. However, for this study, only five colleges were involved in the study. The number of college occupants listed in the schedule includes students, office staff, cleaners, gardeners, and cafe workers. The majority of college occupants are UKM students staying in their respective colleges. The college information are obtained from the UKM Alumni and Student Development Center (PPMPA UKM) consisting the latest source of information i.e. the total number of students enrolling in admission session college 2017/2018. The source of information for the number of college occupants other than students is derived from their respective college office staff. The total number of residents of the college is the total number of residents of the college session of 2017/2018 from August 2017 until June 2018.

Generally, this study is based on quantitative-scientific exploratory perspective, where energy consumption is based on actual reading observed by the energy manager at UKM. This is done through the collection of data at each selected colleges between August and October 2017 as it is the peak period of energy consumption (Khazanah 2018). In addition, researchers also conducted surveys/observations on aspects of wastage and savings made by residents of selected residential colleges.

In addition, informal interviews were also conducted among the electrical engineers, staff from the UKM Energy Management Unit, selected college staffs and students at each selected colleges. It aims to get their views and suggestions to save energy consumption at at the National University of Malaysia. In general, data obtained from the field of primary data can be analyzed using quantitative methods through the basic formula to obtain the average electricity consumption used by a residential dweller taking into account the value of the college's residential charge of RM0.30 per kWh.

Observations were conducted at selected colleges at Universiti Kebangsaan Malaysia. A total of 3 residential colleges are selected and this is the place where researchers find most of the primary data. During fieldwork, the 
researchers recorded electricity consumption readings at the electrical meters in each college. The researcher recorded the reading on a daily basis for a month starting from January 28 to February 26 in the same year of 2018. The observation was conducted twice daily at 7.00 am and 7.00 $\mathrm{pm}$. The period is considered to be an appropriate period of time as it is an early period of semester. The average standard charge rate for electricity consumption is used by a residential college occupant can be seen in the study results and can be compared between the residential colleges on the standard charges. The comparison can be seen in the highest energy consumption of selected colleges. This can provide suggestions on energy saving efforts that can be practiced at the National University of Malaysia.

\section{Research findings}

According to Khazanah (2018), a total of RM23.9 million has been allocated for the payment of electricity utility in UKM for 2017. A total of 60.5 million $\mathrm{kWh}$ of energy or 42.35 million $\mathrm{CO}_{2}$ was generated during the year. The information shows that utility cost on the UKM campus are among the biggest cost that the University manager has to bear. The residential college is one of the largest component in the use of the energy. Table 1 to Table 5 show the usages and charges for the utility cost at all five major colleges in UKM campus.

Table 1: Energy charges and the Maximum Demand (MD) of Kolej Burhanuddin Helmi (KBH) (Aug-Oct 2017)

\begin{tabular}{|c|c|c|c|c|c|}
\hline Month & Usage (kWh) & Charges (RM) & M.D. (kW) & Charges (RM) & Total (RM) \\
\hline August & $40,040.40$ & $12,012.12$ & 144.28 & $4,371.68$ & $16,383.80$ \\
\hline September & $70,544.80$ & $21,163.44$ & 59.23 & $1,794.67$ & $22,958.11$ \\
\hline October & $65,631.00$ & $19,689.30$ & 92.40 & $2,799.72$ & $22,489.02$ \\
\hline Total & $176,216.20$ & $52,864.86$ & 295.91 & $8,966.07$ & $61,830.93$ \\
\hline
\end{tabular}

Table 2: Energy charges and the Maximum Demand (MD) of Kolej Aminuddin Baki (KAB)

\begin{tabular}{|c|c|c|c|c|c|}
\hline Month & Usage (kWh) & Charges (RM) & M.D. (kW) & Charges (RM) & Total (RM) \\
\hline August & $53,694.00$ & $16,108.20$ & 75.84 & $2,297.95$ & $18,406.15$ \\
\hline September & $84,126.00$ & $25,237.80$ & 178.80 & $5,417.64$ & $30,655.44$ \\
\hline October & $79,807.00$ & $23,942.10$ & 186.80 & $5,660.04$ & $29,602.14$ \\
\hline Total & $217,627.00$ & $65,288.1$ & 441.44 & $13,375.63$ & $78,663.73$ \\
\hline
\end{tabular}

Table 3: Energy charges and the Maximum Demand (MD) of Kolej Rahim Kajai (KRK) (Aug-Oct 2017)

\begin{tabular}{|c|c|c|c|c|c|}
\hline Month & Usage (kWh) & Charges (RM) & M.D. (kW) & Charges (RM) & Total (RM) \\
\hline August & $47,824.80$ & $14,347.44$ & 77.32 & $2,342.80$ & $16,690.24$ \\
\hline September & $68,599.30$ & $20,579.79$ & 138.36 & $4,192.31$ & $24,772.10$ \\
\hline October & $64,762.70$ & $19,428.81$ & 152.36 & $4,616.51$ & $24,045.32$ \\
\hline Total & $181,186.80$ & $54,356.04$ & 368.04 & $11,151.61$ & $65,507.65$ \\
\hline
\end{tabular}

Table 4: Energy charges and the Maximum Demand (MD) of Kolej Dato' Onn (KDO)

(Aug-Oct 2017)

\begin{tabular}{|c|c|c|c|c|c|} 
Month & Usage (kWh) & Charges (RM) & M.D. (kW) & Charges (RM) & Total (RM) \\
\hline August & $21,514.00$ & $6,454.20$ & 30.02 & 909.60 & $7,363.8$ \\
\hline September & $48,440.9$ & $14,532.27$ & 113.5 & $3,439.05$ & $17,971.32$ \\
\hline October & $48,156.4$ & $14,446.95$ & 98.79 & $2,993.33$ & $17,440.28$ \\
\hline Total & $118,111.3$ & $35,433.42$ & 242.31 & 7341.98 & $42,775.4$ \\
\hline \multicolumn{7}{c}{ Source: Khazanah (2017) }
\end{tabular}

Table 5: Energy charges and the Maximum Demand (MD) of Kolej Tun Hussein Onn (KTHO) (Aug-Oct 2017)

\begin{tabular}{|c|c|c|c|c|c|}
\hline Month & Usage (kWh) & Charges (RM) & M.D. (kW) & Charges (RM) & Total (RM) \\
\hline August & $26,977.50$ & $8,093.25$ & 48.39 & 1466.22 & $9,559.47$ \\
\hline September & $44,465.50$ & $13,339.65$ & 90.56 & $2,743.97$ & $16,083.62$ \\
\hline October & $38,984.70$ & $11,695.41$ & 98.55 & $2,986.07$ & $14,681.48$ \\
\hline Total & $110,427.70$ & $33,128.31$ & 237.50 & $7,196.25$ & $40,324.56$ \\
\hline \multicolumn{7}{c}{ Source: Khazanah (2017) }
\end{tabular}


The result shows that $\mathrm{KBH}$ recorded electricity consumption of $176,215.80 \mathrm{kWh}$ (Table 1). The KAB recorded amount of $217,627 \mathrm{kWh}$ (Table 2), while KRK recorded at 181, 186.80 $\mathrm{kWh}$ (Table 3). The KDO recorded amount of 118,111.3 kWh (Table 4) and lastly, KTHO recorded at $110,427.70 \mathrm{kWh}$ (Table 5). The table also show that KBH recorded a charge of RM52,864.86 within the 3-month period. The KAB recorded as RM 65, 288.1, KRK (RM 54,356.04), KDO (RM 35,433.42) and KTHO recorded RM 33,128.31. This shows that Aminuddin Baki College (KAB) has the highest electricity consumption reading among selected colleges with reading of 217,627 kWh. Tun Hussein Onn College (KTHO) has the lowest electricity consumption readings compared with the selected colleges with $110,427.70 \mathrm{kWh}$ equivalent of 33,128.31 RM within the 3-month period.

Based on the ratio between utility cost and the number of students, it is found that $\mathrm{KBH}$ is the college with the highest score of $80.8 \mathrm{kWh} /$ student, compared with other colleges of KAB (68.5 kWh/student), KRK (67.1 kWh/ student, KUO (59.9 kWh / student) and KTHO (49.5 kWh / student). The differences of utility cost ratios with total students is about $31.7 \mathrm{kWh} /$ student and the average energy consumption is around $65.2 \mathrm{kWh} /$ student. The findings reveal the imbalance in trend of energy consumption among the colleges. Responses from the Khazanah and College management also revealed the need to study in-depth about it, particularly the college's operations and management factors that may have an impact on these significant differences. However, results relating to Maximum Demand (MD) values have shown that the highest number of students in the KAB (total number of students $=953$ ) resulted in the highest MD value of 441.44 $\mathrm{kW}$, while the lowest MD value was recorded at $237.5 \mathrm{~kW}$. Figure 2 to Figure 4 shows the daily trend of electricity consumption in KRK, KBH and KAB. Daily consumption analysis has found that nighttime energy consumption trends are higher than during the day. Rahim Kajai College (KRK) had the highest reading on February 23, 2018 at night with electricity consumption of $2,767 \mathrm{kWh}$, compared with KBH of 2,265 kWh on February 21, 2018 while KAB of 1,689 kWh on February 13, 2018.

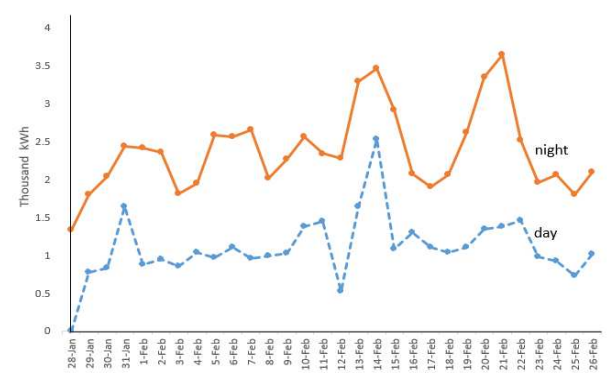

Figure2. Daily trend of electricity consumption of KRK (28 January to 26 Februari 2018)

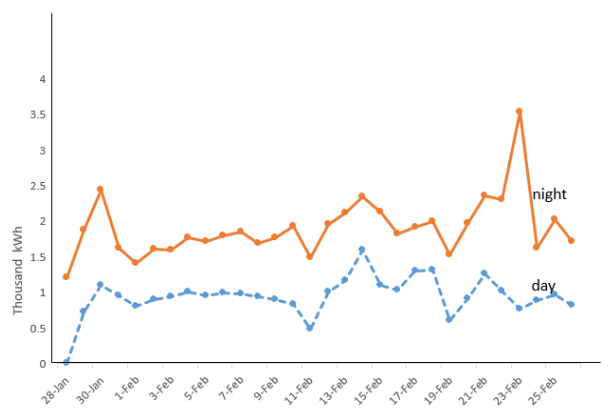

Figure3. Daily trend of electricity consumption of KBH (28 January to 26 Februari 2018)

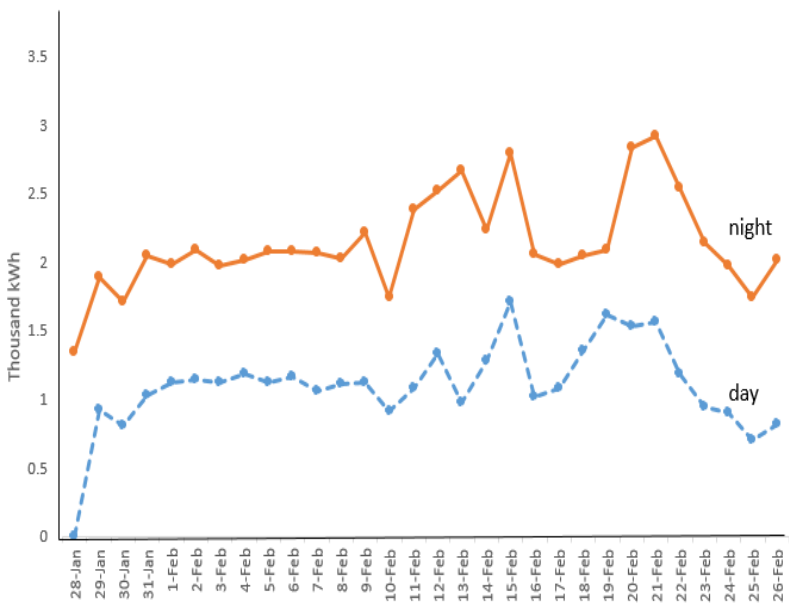

Figure4. Daily trend of electricity consumption of KAB

(28 January to 26 Februari 2018)

The high usage of nighttime compared to daytime can be attributed to learning activities as well as their free times in the residential area. Low electricity consumption during the day is due to the fact that most students are within campus environment to attend their respective classes. The results of this study are equivalent to the study conducted by Mohd Nor et al (2016). The observation revealed that only a small percentage of students do not concerned on their energy savings at colleges. However, the male students are willing to close their lights and fans while leaving their rooms. Ongoing campaigns and reminders from college managers should be done from time to time to ensure electricity savings at the residential colleges. Electricity awareness and savings campaigns should be one of the agendas of student activities in residential colleges. Students and instructors, should be reminded to save electricity by closing electrical equipment such as phone chargers, laptop chargers, lamps, and so forth if they are not used.

In addition, the University's manager also need to think of a comprehensive action plan that is in line with the needs of sustainable campus development in the future. One of the actions that should be taken immediately is to think about the use of energy-efficient air conditioning components. This is because, the cooling aspect of space is one of the largest energy wastage in tropical countries such as Malaysia (Liang \& Jinxing 2015; Jadin et al 2008) In addition, the air conditioner should be maintained regularly so that the air conditioner can function properly. In addition, universities can also diversify renewable energy such as solar energy, wind and biomass in reducing electricity consumption. The use of renewable energy can save the spending on utility bills as well as expanding research and development on new sustainable products.

\section{Conclusion}

This study has identified the trend of electricity consumption in selected residential colleges at Universiti Kebangsaan Malaysia. The results showed that there was a significant difference in the energy consumption trend among the residential colleges. The difference in energy consumption during day and night is also very significant among the residential colleges. The result is expected to be a useful guide in reducing electricity consumption in residential colleges in UKM. It is also will benefited to the energy manager especially in designing and implementing efficient energy saving plans at the their campus. 


\section{References}

[1] Brandon Gollotti (2009). Energy Use in Penn's Student Housing and Techniques to Achieve Energy Reduction: University of Pennsylvania. Senior Seminar Papers. 11

[2] Bernama (14 April 2016) Kerajaan kaji potensi tenaga angin jana bekalan elektrik. Malaysia Kini. Diperolehi daripada https://www.malaysiakini.com/news/337824

[3] Choong Weng Wai, Yin Fong Chong, Sheau Ting Low, Abdul Hakim bin Mohammed (2012). Implementation of Energy Management Key Practices in Malaysian Universities. 2(3), 455-477.

[4] Christopher P. Barlett (2017). From theory to practice: Cyberbullying Theory and its Application to Intervention: Gettysburg College, USA. 72 (2017) 269275

[5] CRED (2009). Carbon reduction @ UKM. Energy efficiency in campus. http://www.ukm.my/energy/

[6] Liang Zhao, Jili Zhang \& Jinxing Ma (2015). The Application of Building Energy Consumption Index in Campus Energy Efficiency Management Platform: Dalian University of Technology. China. Vol. 9, No. 7 (2015), 103-112.

[7] Khaidir, M. 2019. Electricity consumption between residential colleges: A case study at the National University of Malaysia. Thesis. Undergraduate (Geography). UKM unpublished.

[8] Khazanah. (2017) Exclusive interview with Khazanah officers in January 10 ${ }^{\text {th }}, 2017$.

[9] Khazanah (2018). Exclusive interview with Khazanah officers in May 13 $3^{\text {th }}, 2018$.

[10] M. S. Jadin, N. Md. Saad, S. N. S. Ab. Rahman, M. F. Abas, A. H. M. Hanafi \& A. Walik (2008). The Effect of Using Timer to the Split Unit Air-Conditioning Control in UMP's Lecture Halls and Labs: 2nd Engineering Conference on Sustainable Engineering Infrastructures Development \& Management December 18-19
[11] Mohd Noor Azli Ali Khan, Muhamad Syakir Shukor, Mohd Amri Md Yunus, Yanuar Zulardiansyah Arief \& Mohamad Hairil Abdul Ghani (2016). Kajian Penggunaan Peralatan Elektrik di Kolej Dato' Onn Jaafar, Universiti Teknologi Malaysia

[12] Nur Najihah Abu Bakar, Mohammad Yusri Hassan, Hayati Abdullah, Hasimah Abdul Rahman, Md Pauzi Abdullah, Faridah Hussin and Masilah Bandi, (2013). Sustainable Energy Management Practices and Its Effect on EEI: A Study on University Buildings. Proceedings of Global Engineering, Science and Technology Conference 1-2 April. Dubai, UAE. 1- 11.

[13] Olivia Guerra Santin, Laure Itard, Henk Visscher (2009). The effect of occupancy and building characteristics on energy use for space and water heating in Dutch residential stock. 41 (2009), 12231232.

[14] Prashik P. Kamble \& Rahul K. Kamble (2014). Energy Audit of Sardar Patel College, Chandarpur, Central India: Sardar Patel College, Chandrapur. Volume-3, Issue-3

[15] Robin Kundis Craig (2010) Constitutional Contours for the Design and Implementation of Multistate Renewable Energy Programs and Projects. 81 U. Colo. L. Rev. 771

[16] Sanurya Putri Purbaningrum (2014). Audit Energi dan Analisis Peluang Penghematan Konsumsi Energi Listrik pada Rumah Tangga: Universitas Muhammadiyah Surakarta. Vol 15, No.1, 26-33.

[17] Shashi Kant Srivastava (2016). Causal Relationship between Electricity Consumption and GDP: Plausible Explanation on Previously Found Inconsistent Conclusions for India: Indian Institute of Management, Indore, India. 6, 276-281

[18] Tiwi Kamidin (2013). Audit Hijau Penggunaan Elektrik dan Air di Institusi Pendidikan Guru Kampus Batu Lintang Kuching: Jurnal Penyelidikan IPG KBL, Jilid 11, 2013 